\title{
Pintura e interiores burgueses en la Málaga del siglo XIX
}

\author{
Teresa Sauret Guerrero*
}

La incorporación al catálogo de Denis Belgrano de conjuntos decorativos inéditos sirve como pretexto para realizar una relectura sobre la significación de los espacios domésticos en la arquitectura del siglo XIX y el papel que representa la pintura decorativa en ellos.

Through several unpublished pictorial works signed by José Denis Belgrano, this essay studies the meaning and importance of domestic atmospheres and decorative painting into XIX century architecture.

Cuando en el siglo XVIII la nueva arquitectura reclamaba para si la autonomía y de su funcionalidad se derivaba una connotación moral, no se pensó que la nueva clase social emergente, la burguesía, iba a aprovecharse de las infinitas posibilidades que esta nueva concepción del ejercicio de construir iba a aportar al entendimiento y uso de la vivienda.

Ésta, asociada a la idea de progreso, bienestar social y confort (aspiraciones del movimiento ilustrado para todo ciudadano) se iba a convertir en el espacio primordial del desarrollo del individuo en cuanto que se entendía como parte integrante e indisoluble de la primera cédula humana, la familia, unidad que alcanzaba la plenitud de su desarrollo en la esfera de la privacidad, que se desenvolvía en el seno de la vivienda, espacio que se fue entendiendo como el primordial para que se inculcara la formación moral y ética del individuo.

Si Ledoux levantara la cabeza, se espantaría al comprobar que a su propuesta de limpieza, pureza y racionalidad para una arquitectura moderna, en el siglo siguiente se opuso ostentación y recargamiento, no conseguidos tanto en el plano arquitectónico como en el de enmascaramiento de los espacios con unos complementos que se usaban y utilizaban como instrumentos representativos, en un uso travestido de la primigenia idea de confort y progreso.

En ese maquillaje de la nueva arquitectura mucho tuvo que ver la decoración de sus interiores, y no estoy hablando del mobiliario sino de la disolución del sentido de las estructuras y de los espacios mediante la distorsión que suponía las complejas decoraciones que se aplicaron a sus techos y muros, elementos que transformaron los conceptos de racionalidad, funcionalidad y valores de modernidad, en espacios para la ficción y el aparato.

Es por ello que la investigación sobre la decoración de interiores de la vivienda burguesa decimonónica es más significativo de lo que a primera vista pueda parecer, ya

SAURET GUERRERO, Teresa, "Pintura e interiores burgueses en la Málaga del siglo XIX", en Boletín de Arte, $\mathrm{n}^{\text {os }}$ 26-27, Universidad de Málaga, 2005-2006, págs. 413-436. 
que su análisis debe hacerse en función de comprender su utilidad y representatividad, porque a través de ellas penetraremos más acertadamente en la personalidad de la ciudad comprendiendo los intereses de sus habitantes, especialmente aquellos que dirigían la ciudad, política y económicamente, y dieron el talante personal a la población local.

No mucho se ha avanzado en este campo desde que en 1965 Manuel Jorge Aragoneses estudiara la pintura decorativa en Murcia $^{1}$, no existiendo hasta el momento en la historiografía española una monografía general sobre el tema, constituyendo el asunto pequeñas parcelas en estudios cuyo objetivo es la pintura, la arquitectura, o la vivienda del siglo XIX en localidades específicas.

En cuanto al caso concreto de Málaga, salvo esa limitada aproximación que hice hace cerca de veinte años ${ }^{2}$, poco más se ha avanzado en el tema ${ }^{3}$, probablemente porque la destrucción sistemática del caserío decimonónico malagueño, nos esta privando de poder ampliar esa primitiva relación, aunque, también es verdad, que excepcionalmente aparecen conjuntos, desplazados de sus ubicaciones originales, que están siendo rescatados por el coleccionismo privado y justifica este nuevo acercamiento al tema con el fin de ampliar el catálogo existente ${ }^{4}$.

Hoy dia, retomando la línea que iniciamos en 1986, se puede decir que son escasos los ejemplos que se conocen en Málaga y casi todos pertenecen a edificios públicos: El Conservatorio María Cristina, el Teatro Cervantes, el Palacio Municipal y algún resto en establecimientos comerciales (antigua joyería Ghiara en calle Granada), pero la documentación informa que los más numerosos se encontraban en los domicilios privados de la aristocracia y alta burguesía, y, en una ciudad de las características sociales como Málaga, en buena parte de las viviendas de una burguesia de consolidada posición que no llegaron a formar parte de la oligarquía local pero que sí jugaron un papel dominante en la sociedad civil de la época. Lamentablemente la mayoría de estos conjuntos decorativos han desaparecidos. Las razones pueden estar en que, como elemento de complemento de la arquitectura, se ha visto sometida a todo ese proceso destructivo al que hemos aludido más arriba.

La sistemática destrucción del patrimonio inmueble decimonónico, tanto del casco histórico como de las zonas residenciales tradicionales (Caleta, Limonar, Pedregalejo), ha provocado la desaparición de estas decoraciones, que en rara ocasión se han salvado del derribo del edificio. Probablemente debido al mal estado de conservación,

\footnotetext{
* Universidad de Málaga.

JORGE ARAGONESES, M.: Pintura decorativa en Murcia, siglos XIX y XX. Murcia, 1965.

SAURET GUERRERO, T.: El siglo XIX en la pintura malagueña. Málaga, Universidad, 1987, págs. 263-306.

${ }^{3}$ Francisco García Gómez, dentro de su completo trabajo sobre la arquitectura doméstica local en el siglo XIX ha enriquecido el catalogo, que en su día elaboré de pintura decorativa malagueña, incluyendo las decoraciones de los inmuebles $\mathrm{n}^{\circ} 12$ del Paseo de la Farola y finca San José de los Heredia, vid. GARCÍA GÓMEZ, F.: La vivienda Malagueña del siglo XIX. Arquitectura y sociedad. Málaga, Universidad-Consejo Social-Cajamar, 2000, págs. 680-683.

4 Recientemente la entidad Unicaja ha adquirido, restaurado y recuperado un ciclo completo perteneciente a dos inmuebles y han aparecido parte de estos conjuntos en colecciones particulares. Al respecto ver, SAURET GUERRERO, T: Pintura malagueña en colecciones particulares. Málaga, Ayuntamiento, 2002, págs. 38, 69 y SAURET GUERRERO, T.: Denis, Decoraciones, Málaga, Unicaja, 2003.
} 


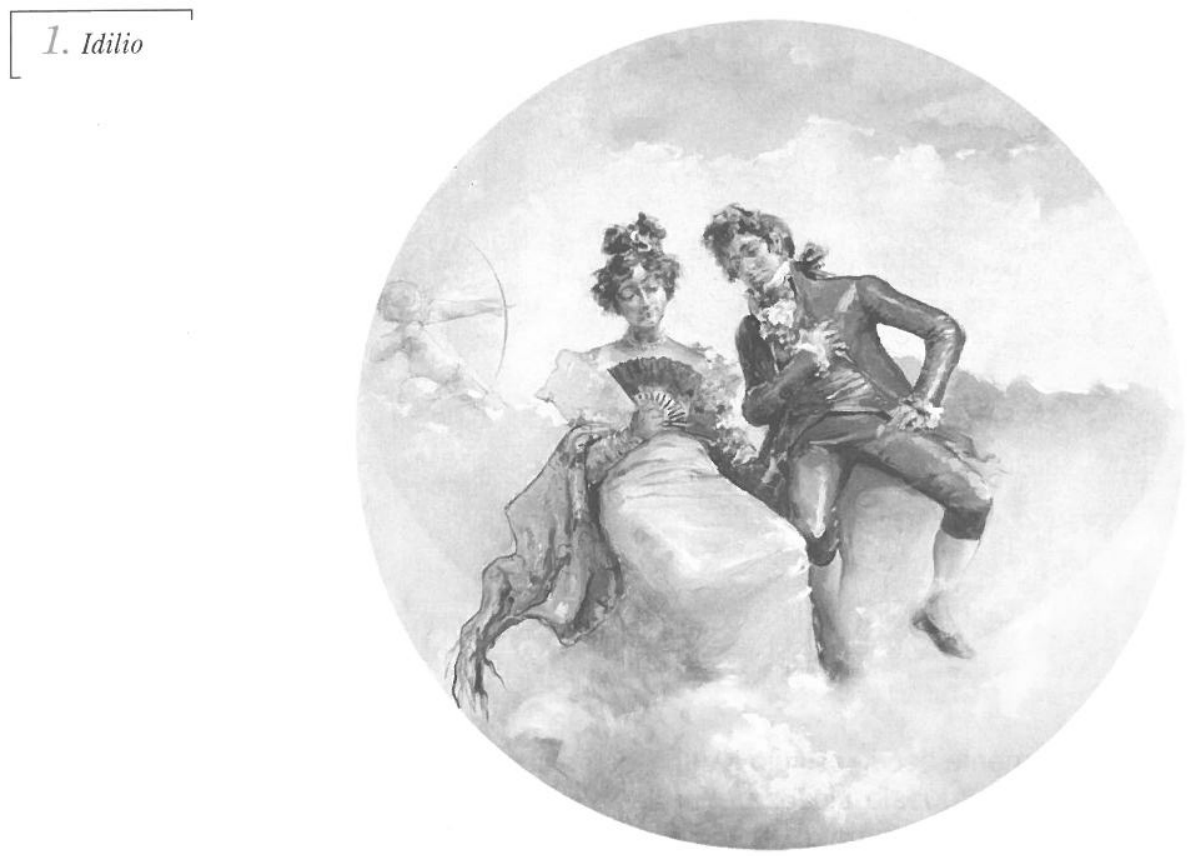

la pérdida de significado al disociarse de su espacio original, su iconografía, técnica, tamaño y soporte, ha contribuido a que no se haya desarrollado sobre ella un interés por su conservación, salvo escasas excepciones que por su calidad o significación le han otorgado el privilegio de su rescate.

La recuperación de algunos conjuntos situados en inmuebles privados, pertenecientes todos a los pinceles de José Denis Belgrano, constituyen una razón para volver sobre el tema y aportar nuevos datos sobre el mismo.

\section{BURGUESÍA Y HOGAR: LA SIGNIFICACIÓN DE LOS ESPACIOS INTERIORES}

La casa, es el vestido de la familia. Contribuye a servirle de envolvente, a protegerla y a acoplarse a todos sus movimientos... ella, por medio de su planta, responde al modo de vida que el clima y la civilización le impone... por su conjunto hace mil revelaciones acerca del gusto público, de los usos y costumbres del hogar y ofrece numerosos puntos de vistas sobre el tipo de las relaciones sociales ${ }^{5}$.

Asi se entiende a mediados del siglo XIX, y en la Francia del Segundo Imperio ( $y$ en toda Europa, España incluida), el espacio por antonomasia para el desenvolvimiento de las relaciones familiares.

DALY, C., Lárchitecture privée au XIX siècle sus Napoleón II., 3 Tomos, París, Ed. Morel, 1864. 


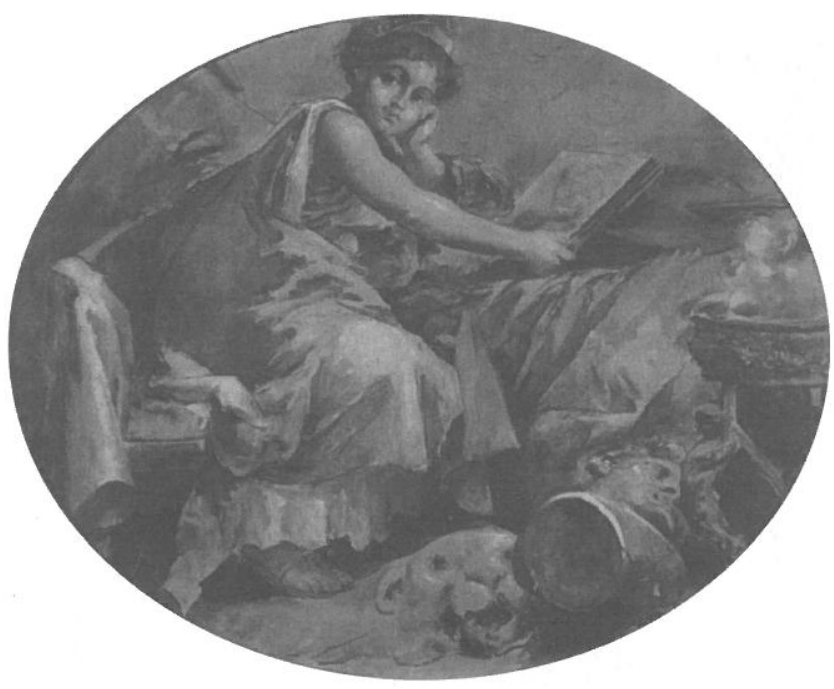

2. La modelo

Prácticamente desde el siglo XVIII, y como consecuencia de la revolución ilustrada por la que la burguesía alcanza el poder e impone su filosofía de vida, la familia se va a convertir en el átomo de la sociedad civil, y la casa el espacio de la convivencia familiar. A partir de ese momento, y a lo largo del siglo XIX, se construirá el binomio familia-hogar como una relación indisoluble en el que la sociedad civil tiene su marco básico de desarrollo.

Si la familia, fundamentada en una estructura patriarcal, con los ámbitos de desarrollo entre lo público y lo privado perfectamente estipulados por la división de competencias entre el padre y la madre, era la plataforma en donde se formaba y desarrollaba el individuo, su lugar de desenvolvimiento era el hogar, la casa, que no se concebía exclusivamente como un refugio, sino el pilar del orden social, espacio en donde se facilita que las familias pudieran realizar con fluidez las funciones moralizantes.

En este sentido Kant dirá: La casa, el domicilio, es el único bastión frente al horror de la nada, la noche y los oscuros orígenes; encierra entre sus muros todo lo que la humanidad ha ido acumulando pacientemente por los siglos de los siglos; se opone a la evasión, a la pérdida, a la ausencia, ya que organiza su propio orden interno, su sociabilidad y su pasión. Su libertad se despliega en lo estable, lo cerrado, y no en lo abierto ni lo indefinido. Estar en casa es lo mismo que reconocer la lentitud de la vida y el placer de la meditación inmóvil... La identidad del hombre es por tanto domiciliaria, y ésta es la razón de que el revolucionario, el que carece de hogar y de morada, y que tampoco tiene, por tanto, ni fe ni ley, condense en sí mismo toda la angustia de la errabundez.... El hombre de ninguna parte es un criminal en potencia ${ }^{6}$.

${ }^{6}$ Cit. en ARIÉS, P., DUBY,G.: Historia de la vida privada. Sociedad burguesa: aspectos concretos de la vida privada. Madrid, Taurus, 1991, pág. 10. 


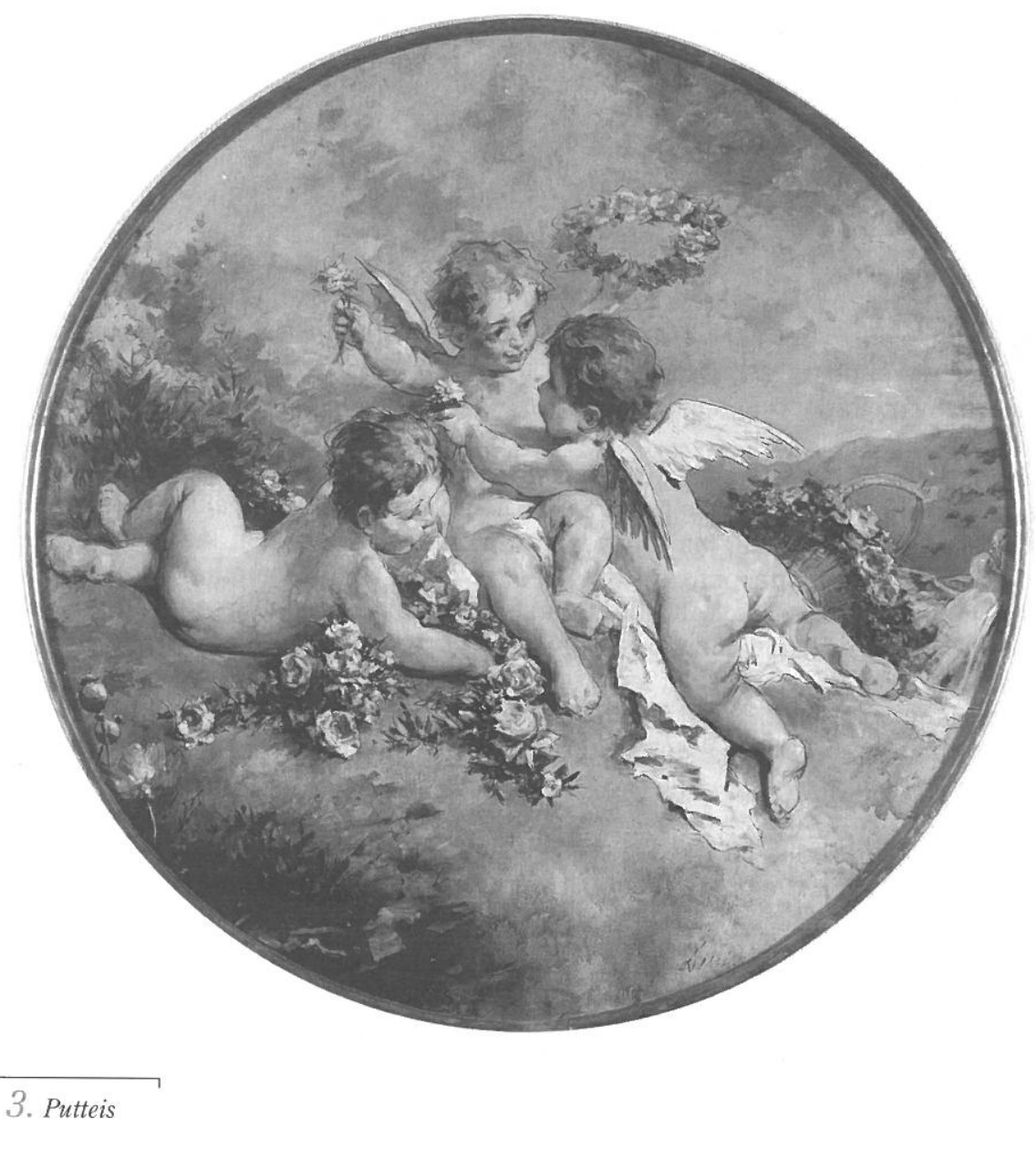

Frente a los peligros de la amoralidad externa, el territorio para la intimidad cotidiana debía reunir todos los condicionantes para atraer y aglutinar a los miembros de la familia, del descanso al ocio.

Esta idea dimensiona de una forma diferente el hábitat familiar, ya que la hace depender de una estructuración espacial adecuada para el desarrollo de las funciones de esa "escuela" de moral (burguesa) que debía ser la casa, hasta el punto que, teorizando sobre ello, se dirá que: ..la casa-habitación es la síntesis, el resumen de la manera de ser de los pueblos y de sus aspiraciones?

FERRANT, A.: Discursos leidos ante la Real Academia de Bellas Artes de San Fernando en la recepción pública del Sr. D... el día 20 de diciembre de 1885. Madrid, Imp. de M. Tello, 1885, pág. 8. 
En principio se la somete a ese juego de la doble moral burguesa ${ }^{8}$ y mientras para los exteriores se le exige sencillez, en el interior se desarrolla todo un discurso de ostentación que es referente del posicionamiento social del propietario.

Los principios de racionalidad y uniformidad que marcan la arquitectura moderna se aplicarán también a la arquitectura doméstica, que se someterá a la rigidez de la parcelación urbanistica y se planteará en un diseño en profundidad, mas que en anchura, consecuencia de esa especulación del suelo que traerá las desamortizaciones. El lujo de la vivienda está en la funcionalidad y en la uniformidad, en la aplicación de los nuevos materiales, como el hierro y el vidrio, y en la traducción del lenguaje arquitectónico moderno en las fachadas, en donde la coherencia entre estructura interior y la exterior y su traducción hacia el exterior, es fundamental ${ }^{9}$.

Si reparamos en la arquitectura malagueña, ciudad que constituye un modelo de referencia para todo ello, comprobaremos como esos principios aludidos se resuelven. Sólo en la Alameda, las fachadas se monumentalizan con las portadas y los amplios halls de entrada, pero la Alameda es territorio de la oligarquía y alta burguesía y es prácticamente del siglo XVIII, aún asi, el lujo exterior lo marca más la amplitud en metros de las fachadas que los elementos decorativos de ostentación, porque su grandeza radica, precisamente, en la sobriedad y elegancia de sus exteriores. Pero si nos trasladamos al interior del Centro Histórico, o en la extensión que supone las parcelas hacia el sur desde la Alameda, prácticamente construidos en el S. XIX, se comprueba los denominadores comunes de esta arquitectura: estrechez de las fachas, articulación de las mismas en función de los vanos y la racionalidad en la disposición de estos y la sobriedad en los elementos decorativos, más concebidos como "gestos" referenciales del nuevo discurso arquitectónico, que como elementos de ostentación.

Sin embargo, los interiores de la arquitectura doméstica del siglo XIX, son territorio del lujo, de mayor a menor grado económicamente hablando, y trataran de reflejar ese ascenso social alcanzado por el estamento, como consecuencia de la aplicación de sus principios: orden y laboriosidad, que tiene como fruto la prosperidad y el bienestar, entendido, cada vez más, como calidad de vida.

Siguiendo un razonamiento kantiano habria que recordar que es precisamente la moral burguesa la que, como una novedad, contempla el factor económico, entendido como prosperidad, como sinónimo de felicidad, por lo tanto, hay que publicitar ese bienestar con gestos llamativos que hagan referencia al lujo, especialmente en lo privado, en la casa, como espacio territorial de su dominio y de ella, las dependencias para la participación social.

De la remodelación de estos interiores será responsable, también, la industrialización, que hará modificar la mentalidad de la sociedad repercutiendo en el cambio de criterios y exigencias de la burguesia, que cada vez más, según los diferentes niveles sociales, demandaran unas condiciones para sus habitaciones.

ARANGUREN, J.L.: Moral y sociedad. Madrid, Cuadernos para el Diálogo, 1970.

HERNANDO, J.: Arquitectura en España 1770-1900. Madrid. Cátedra, 1989, págs. 427-442. 


\section{Putteis}

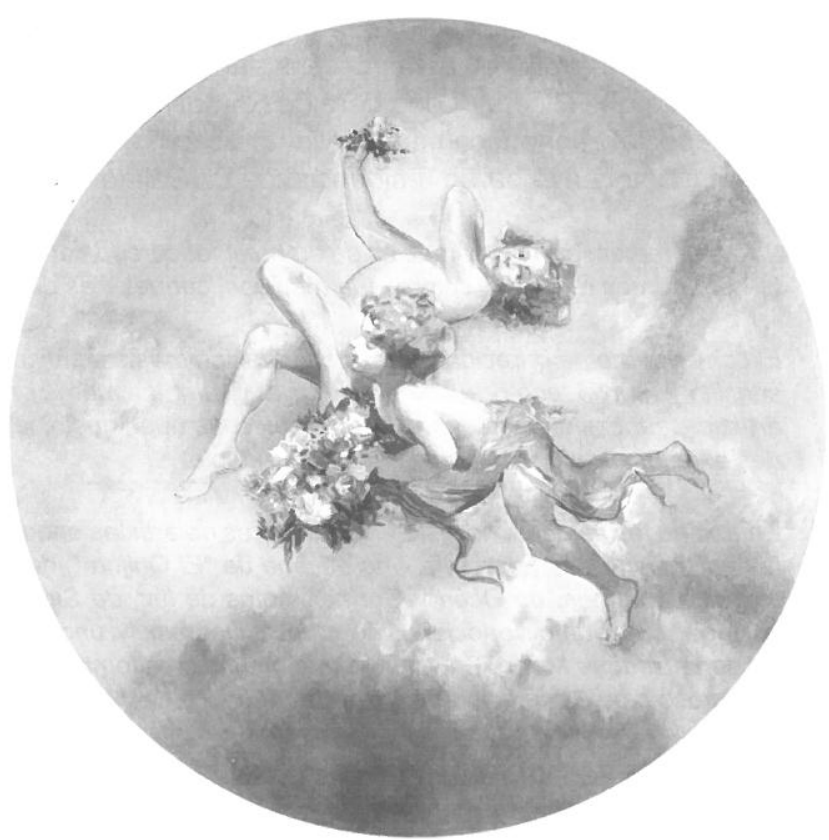

Teóricos de la arquitectura de la época dirán:

Lo que ayer era un lujo asequible sólo a reducidisimo número de felices mortales, es hoy patrimonio de las clases modestas. Y como, además se han despertado las aficiones artísticas, el deseo de bienestar y cierto gusto elegante, basados, sin duda alguna, en la educación y mayor cultura, y acrecentados por la facilidad de comunicaciones, por los certámenes y exposiciones y por la universalidad del comercio, la casa, donde todo esto se refleja, es, en los tiempos modernos, el símbolo de la civilización $n^{10}$.

De peldaño a peldaño social, se tratará de emular los usos de las clases altas y estos interiores domésticos se cuidarán con un meditado plan decorativo que irá desde el tratamiento de los muros a la decoración mobiliar y siempre en correspondencia con el status de su propietario, aunque los signos de bienestar no sean siempre reales, ya que los deseos de ostentación superarán a veces la categoría del dueño de la casa. Recordemos en Málaga el apodo que recibió el barrio de la Victoria: "de chupa y tira", precisamente como aplicación a este doble juego de la apariencia y la realidad ${ }^{11}$.

${ }^{10}$ FERRANT, A.: Discursos... Op. cit., pág. 26.

11 QUILES FAZ, A., Málaga y sus gentes en el siglo XIX. Retratos literarios de una época. Málaga, Arguval, 1995, págs. 72-75, 84-86. El dicho hace alusión a la económica sopa de almejas, base de la alimentación de la población de ese barrio y de las clases medias bajas, que por liberar excedentes para la ostentación economizaban en la comida. 
La literatura de la época se hará eco de esta lectura sociológica y abundarán los relatos donde se expliciten estas circunstancias. Traemos, como un ejemplo significativo, el retrato que Ricardo León hará de Rafael Montes, empresario recién ascendido a la clase social económicamente sólida pero con escasa formación estética y propietario de un hotel en el barrio residencial de La Caleta denominado "Villa Trini":

...Rafael me enseña las estancias de su hotel, decorado con lujo extravagante y pueril, muebles y adornos de bazar, colores inarmónicos, coqueterias de filisteo.

El comedor me ha parecido quizás la habitación mas simpática de la casa; ...es un aposento sencillo y amplio, con grandes ventanas al jardín; los muros ornados con lindos azulejos de artistica fabricación malagueña; los muebles, de buen gusto, la elegante chimenea, los grandes espejos, producen una impresión agradable.

En uno de los salones, he visto algunas obras de artistas andaluces y levantinos; unos apuntes valencianos de Ferrándiz, una escena de "El Quijote", de Moreno Carbonero; flores, de Nogales; marinas, de Ocón y Gartner; notas de luz, de Simonet; pasteles, de Martínez de la Vega; un apunte veneciano, de Muñoz Degrain, y unos graciosos relieves del escultor rondeño Enrique Marin. En el suelo una magnífica alfombra alemana, de admirable factura y primoroso dibujo, imitación de una vidriera gótica ${ }^{12}$.

Sería muy interesante detenernos en esa selecta representación de pintores locales, porque su presencia responde también a esos mismos criterios de representatividad, como nos sugiere la relación tema/especialidad y autor, pero en esta ocasión lo que nos interesa es imaginarnos los ambientes y las intenciones representativas de los objetos de decoración que contienen.

Según el texto anterior, se entiende que su diseño y decoración era una cuestión muy medida. Todos y cada uno de sus espacios estaban destinado a un uso y una función y todos y cada uno de los detalles de amueblamiento de éstos debian responder a estos criterios.

La estructura de los interiores de la vivienda doméstica atendía a una división básica entre los espacios para lo público y lo privado, regentados ambos y respectivamente por el padre-hombre, madre-mujer, por lo que su funcionalidad debía corresponderse igualmente con estos principios.

El ámbito de lo privado lo constituía los dormitorios, cuartos de los niños y de la servidumbre y las dependencias de servicios y complemento que se articulaban por pasillos y patios. Era el dominio de la madre-mujer y espacialmente se situaban en el interior de la vivienda.

La esfera de lo público era competencia del padre-varón, se ubicaba hacia el exterior y lo componía el comedor principal, despachos, bibliotecas y salones: "de estar", de lectura, de tertulias, de celebraciones. Era el espacio de/para la representación y aunque su control era masculino su ambientación era competencia de la mujer pues,

${ }^{12}$ LEÓN, R., Comedia sentimental. S/L, Samarán Ed., 1958, págs. 64-65. 


\section{Putteis}

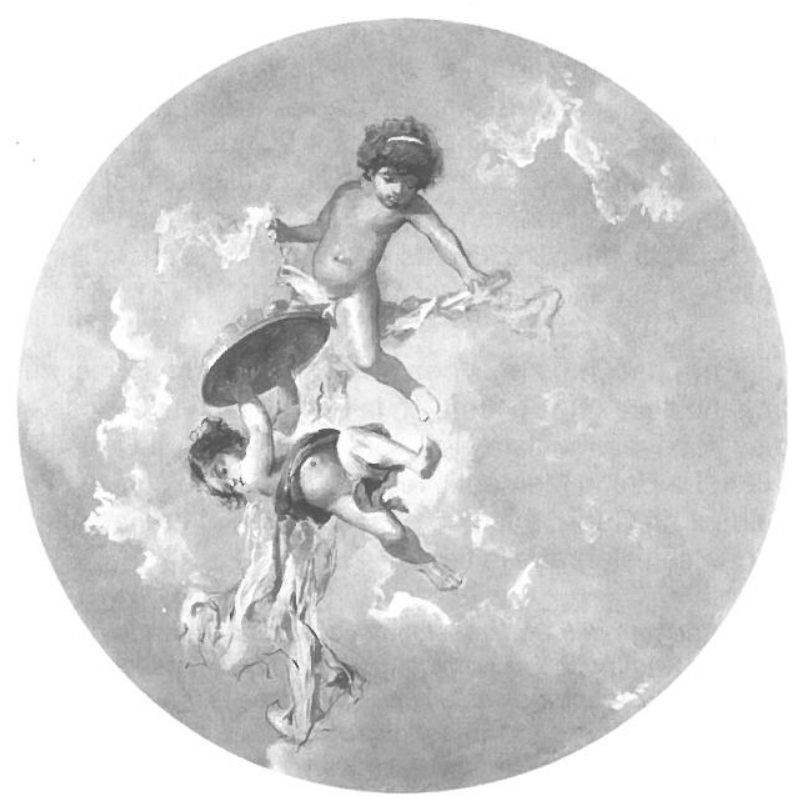

al fin y al cabo, en esa división de funciones del modelo de comportamiento burgués, la casa formaba parte del ámbito de lo privado y en él "reinaba" la mujer ${ }^{13}$. Suya era, pues, la competencia de su decoración.

El mismo Ricardo León, no dejará dudas sobre ello, cuando justifica la labor femenina en el hogar de Rafael Montes con las siguientes palabras: ...es el hada de este hogar..., como mujer, al fin, son de ella innato el buen gusto y el sentimiento de la belleza; gracias a esta dulce señora, la casa del burgués, desdeñoso del arte, tiene un rincón apacible y aristocrático ${ }^{14}$.

A medida que la burguesía va consolidando su posición hegemónica, los signos expositores de su status se convierten en un discurso cuidado y perfectamente elaborado. No van a ser sólo los signos externos de apariencia sino, muy especialmente, aquellos que, por cotidianos e íntimos como es el hogar, son más claramente expositores de la condición social de sus habitantes. La casa se convertirá, entonces, no solo en el núcleo de la vida familiar y escenario de la vida privada, sino especialmente en el teatro de la vida burguesa, de ahí que el espacio de lo público en la vivienda se convierta en el expositor de esa representación, del status de la familia, de esa familia.

${ }^{13}$ SABATER et ali: Mujeres, espacio y sociedad. Hacia una geografia del género. Madrid, Síntesis, 1991.

${ }^{14}$ LEÓN, R.: Comedia... Op. cit. pág. 65. 
El mayor cuidado recaía en los espacios domésticos públicos en donde se acumulaban objetos de calidad y especialmente artísticos dando como resultado unos espacios de lujo que llamaban la atención de sus visitantes. En el caso concreto de Málaga, ya en 1835, antes de que la industrialización trajera a la ciudad la bonanza económica que la hizo la primera ciudad industrial de España, un viajero ingles, Inglis, comentaba de los interiores de las casas de la Alameda: ...el interior de muchas de estas casas me pareció más espléndido que cualquier otra cosa de las que había visto antes en España ${ }^{15}$.

Para hacernos una idea de estos interiores y del entendimiento de la función propagandística que se tenía en la época, resulta curioso observar como la prensa periódica hace referencia a ellos como signos de una identificación cualificada del lugar. En 1894, La Unión Mercantil, recogia un evento social, el cumpleaños del hijo de Plácido Gómez de Cádiz, y lo que destacaba de él era la categoría del espacio doméstico en donde se celebraba la fiesta:

\begin{abstract}
...Las paredes de los salones están casi tapizados de cuadros, formando una especie de pequeño museo pictórico tanto en el arte retrospectivo como en el de nuestros dias, distinguiéndose entre estos últimos preciosas pinturas de la actual escuela malagueña, que hoy puede llamarse asi no por adulación nuestra, sino por la sanción explicita de las Exposiciones extranjeras.
\end{abstract}

Otros muchos objetos de arte se destacan en aquellos salones, como tibores, grupos de cerámica riquísimos por cierto, espejos del mejor gusto y muebles de la mejor confortabilidad ${ }^{16}$.

El lujo comenzaba por el material de los muebles, de palo santo como en la casa de los Loring (Alameda 49) caoba, la mas generalizada, en la vivienda de Miguel Crooke; sedas, bronces, tapices y alfombras de piel en las de Obdulio Castell y Enrique Heredia, y así un largo etc. Curiosamente, las testamentarías dan cuenta que la calidad del mobiliario no era siempre entendida para recreo del uso común sino que se consideraban como un valor económico y cotizable que formaban parte de la riqueza patrimonial de la familia ${ }^{17}$.

Sin duda, uno de los mas significativos gestos referenciales de la posición socioeconómica de privilegio lo constituía la decoración mural de sus interiores.

\footnotetext{
${ }^{15}$ INGLIS, H. D.: Spain in 1830. Londres, 1831. Cit. por MAJADA NEILA, J.: Viajeros románticos en Málaga. Salamanca, Lib. Cervantes, 1986, pág. 40. Esta suntuosidad motiva que en las guías comerciales se incluyan referencias a estas viviendas, así en la Guía de F.D. y LÓPEZ: Manual del viajero de Madrid a Granada y Málaga. Madrid, Imp. P. Montero, 1853, se comenta: ...entre los edificios nobles se destaca la casa de Valentín Martínez, la de Carlos Larios por su preciosa escalera de mármol y la de Quirós en la Alameda.

${ }_{16}$ La Unión Mercantil, 22 de enero, 1894.

${ }^{17}$ RAMOS FRENDO, E.: El coleccionismo decimonónico malagueño. Málaga, Universidad, 2001, (Tesis doctoral inédita).
} 


\title{
ARQUITECTURA Y PINTURA DECORATIVA. UN PASEO POR LOS INTERIORES MALAGUEÑOS
}

\author{
El arte decorativo, tiene siempre un destino, \\ una aplicación, forma parte integrante de un conjunto, \\ y por lo tanto, ha de tener muy en cuenta \\ las necesidades que el uso impone a la formals.
}

El empleo extendido de la pintura decorativa en los ambientes domésticos burgueses se produce a partir de finales del siglo XVIII y, especialmente, durante todo el siglo XIX. Es consecuencia tanto de una postura historicista, en la que se recurre a modos del pasado, como de una dinámica ideológica, en cierto sentido nueva, instaurada por la clase social emergente del siglo que fue la burguesía.

Interpretar sus razones no resulta tan simple como entender que este ejercicio es consecuencia de un rescate de usos tradicionalmente entendido como de prestigio en la historia. No fue tanto la moda pompeyana de raigambre ilustrada, por deseo de emular los ambientes romanos, como el rescatar para el presente la utilidad que tenían los mensajes que se pueden transmitir a través de esta practica decorativa. Como dirá Alejandro Ferrant, la pintura decorativa es ...el comentario perpetuo del edificio $^{19}$, una clave que históricamente estaba perfectamente asumida y se había practicado con la máxima solvencia. Bástenos recordar el ciclo sobre la Guerra de Troya de Polignoto para los propileos de la Acrópolis ateniense y la creación de la nueva imagen de poder de Atenas por Pericles, o los frescos de Miguel Ángel en la Sixtina y el programa doctrinal de Julio II.

Por ello, su relato icónico se adaptará a la función del espacio y, aunque su sentido sea exclusivamente ornamental, detrás del motivo iconográfico siempre habrá un discurso expositor de los mensajes de su promotor.

Pero hay que distinguir entre la pintura decorativa para edificios públicos y la destinada a inmuebles de uso privado. Si en los primeros el programa iconográfico suele ser construido sobre un discurso más amplio, que compite a otros sujetos ornamentales y más lugares de ubicación, en la arquitectura doméstica su función suele ser meramente decorativa, aunque su contenido fuera el de hacer exposición del prestigio social de su promotor.

En el sentir de la época se tenía muy estipulado las competencias en esta materia y al teorizar sobre ello se dirá:

Verdad es que, asi como el aspecto exterior de la casa es una especie de homenaje al público en general que la ve, una condescendencia con el gusto dominante y una sumisión a las leyes del conjunto, su decoración interior ha de ser subjetiva, reflejo de los gustos, aficiones

\footnotetext{
${ }^{18}$ FERRANT, A.: Discursos... Op.cit. pág. 8
}

${ }^{19}$ Op. cit., pág. 9 
y costumbres de sus moradores, $y$ ha de estar en perfecta relación con las ideas de éstos y su posición en la sociedad ${ }^{20}$.

El hecho de que en la Málaga decimonónica proliferaran los interiores decorados con pinturas, ejecutados por las más prestigiosas firmas de la época, es referente de la personalidad que alcanzó la ciudad durante ese siglo. Porque se tiene que conjugar: economía y progreso con una sociedad consciente de su posición (de lo que significa su status y el deseo de reafirmación) y con un nivel cultural y artístico capaz de desarrollar el encargo y su ejecución, a la vez que con capacidad para entender los significados de estos gestos.

Lo que quiero decir es que no solo fue dinero, que lo hubo, sino también una conciencia estética que trasladaron a los usos cotidianos, porque el embellecimiento de los interiores no se limitaron a los espacios de representación de la burguesía media y alta, sino también a los lugares comunes de los edificios de viviendas destinados a niveles sociales inferiores dentro del estamento burgués, que supieron demandar la dignificación de sus espacios desde los complementos ornamentales.

Un paseo por el Centro Histórico de Málaga nos hará descubrir portales alicatados o estucados, techos de escaleras decorados o pasillos pintados, como expresión de ese deseo por el confort de la sociedad malagueña decimonónica ${ }^{21}$.

Que duda cabe que la pintura decorativa ocupó la posición de privilegio en la decoración de los inmuebles. Lamentablemente pocas han llegado hoy día en sus lugares de origen, como ya he comentado.

En Málaga, los conjuntos decorativos más sobresalientes se sitúan en edificios públicos y son una expresiva muestra de su práctica en la España del momento. Sin duda es el techo del Teatro Cervantes, realizado por Bernardo Ferrándiz, el que representa la "modernidad" (y pongo el término entre comillas) en el género, sencillamente porque Ferrándiz se aleja de usos comunes y se olvida de "rompimientos", celajes y mitologías para interpretar una supuesta escena cotidiana en clave de Alegoría, la de Málaga, significando su prosperidad a través del progreso que genera su economia, que hace consecuencia, entre otras claves, de su historia y geografía ${ }^{22}$.

Ferrándiz hizo lo mismo que Courbet en su famoso L'atelier, pinto la realidad de Málaga desde la inmediatez de lo cotidiano pero sin sustraerse a una lectura conceptual que convertía el relato en una metáfora, la de la felicidad a través del progreso, visto como sinónimo de lo paradisíaco ${ }^{23}$.

${ }^{20}$ REPULLES Y VARGAS, J. M" a $^{\text {: }}$ "La casa-habitación moderna desde el punto de vista arquitectónico", Discursos leídos ante la Real Academia de Bellas Artes de San Fernando en la recepción pública del Excmo. Sr.,,, el día 24 de mayo de 1896. Madrid, Imp. Y Lit. del Asilo de Huérfanos del Sagrado Corazón de Jesús, 1896, pág. 27.

${ }_{21}$ GARCÍA GÓMEZ. F.: La vivienda malagueña...ob. cit, págs. 591 y ss.

22 SAURET GUERRERO, T.: "La decoración pictórica del Teatro Cervantes de Málaga”, Baética, n 2 (I), Universidad de Málaga,, 1979, págs. 197-200.

23 SAURET GUERRERO, T.: Bernardo Ferrándiz Bádenes (Valencia 1835-Málaga 1885) y el Eclecticismo pictórico del siglo XIX. Málaga, Benedito Editores, 1996, págs. 83-84, 265. 


\section{Musa}

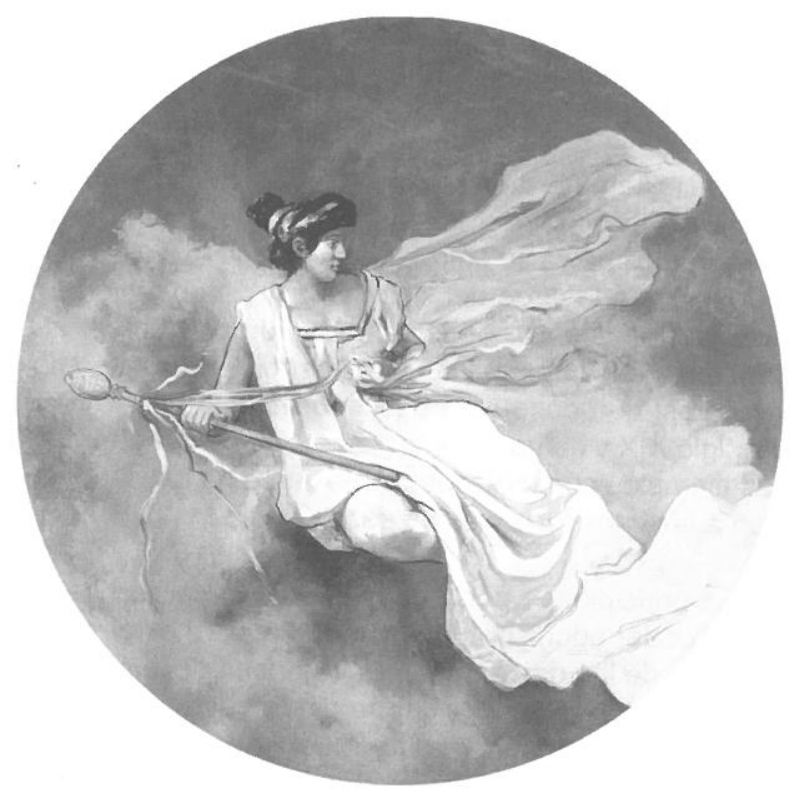

Algo similar habia hecho Fortuny para el palacio de los duques de Riansares en la Avenida de los Campos Elíseos de París, en donde María Cristina e Isabel II presencia unas maniobras militares, supuesta escena de género que contenia un claro mensaje de propaganda política para la monarquía en el exilio.

Pero Ferrándiz era una excepción entonces en Málaga porque, paralelamente, también en 1870, El Liceo Artístico y Literario decora el techo de su salón de actos con escenas alegóricas y mitológicas en unos lenguajes diametralmente opuestos. Los de Denis, de los que después hablaremos, en un clasicismo repleto de gestos tradicionalistas ${ }^{24}$ y La coronación de Dante de Martínez de la Vega, en un desfasado lenguaje romántico-nazareno ${ }^{25}$.

Otra historia es la del salón de plenos del Palacio Municipal, en donde Muñoz Degrain y César Álvarez Dumont vuelven a la metáfora desde lo inmediato de los episodios representativos escogidos ${ }^{26}$, pero las fechas, 1920, nos alejan del discurso decimonónico que nos ocupa.

24 SAURET GUERRERO, T.: José Denis Belgrano: Pintor malagueño de la segunda mitad del siglo XIX. Málaga, Ed. Museo Diocesano de Arte Sacro, 1979, págs. 92-94.

${ }^{25}$ SAURET GUERRERO, T.: Joaquín Martínez de la Vega (1846-1905). Málaga, Ed. Colegio de Arquitectos de Andalucía Oriental, 1990, págs. 36, 40, 64.

${ }^{26}$ SAURET GUERRERO, T.: El Siglo XIX ...ob. cit. págs. 287-289. SAURET GUERRERO, T.: "La pintura: historia de una colección. Politica y mecenazgo" en MORALES, J.M., SAURET GUERRERO, T.: (Ed.), Patrimonio artístico y Monumental. Málaga, Ed. Ayuntamiento, 1990, págs. 179-214. 
En cuanto a la decoraciones de inmuebles privados se puede decir que constituyó una práctica generalizada, ajustándose sus características a los niveles económicosociales de sus promotores.

Esa sistemática destrucción del patrimonio arquitectónico decimonónico malagueño ha tenido, como una consecuencia colateral, la pérdida de las decoraciones de interiores como ya se ha referido, y no me estoy refiriendo a los innumerables derribos producidos a lo largo del siglo XX por circunstancias históricas excepcionales, como pudo ser el incendio de la casa de Tomás Heredia al comienzo de la Alameda, sino también a ese criterio actual, tan generalizado, de respetar las fachadas y destruir los interiores, que denota un desconocimiento absoluto de los principios arquitectónicos del siglo XIX y de un mínimo respeto por lo patrimonial. Sin embargo, pese a los escasos ejemplos conservados, como ya se ha indicado, se puede realizar una aproximación a las características de esos trabajos.

En principio, se podría pensar que la calidad del producto tiene correspondencia con el poder adquisitivo del comitente, pero esto no es exactamente cierto. Las decoraciones de las dos principales viviendas de la época: las casa-palacios de las fincas San José y La Concepción, propiedad de los Heredias y Loring-Heredia respectivamente, que aún conserva parte de su decoración mural, constituyen meros trabajos decorativos, sin embargo, se tiene referencia de inmuebles de la burguesía media del Centro Histórico realizados por firmas importantes del centro artístico malagueño, como pueda ser Denis. Esto nos indica que fue la connotación de prestigio que conllevaba este modo pictórico, el principal móvil de su práctica.

Las más antiguas decoraciones de las que se tienen referencias son las de las fincas San José y La Concepción ${ }^{27}$. La primera, de anterior fecha, desplegó todo un programa decorativo en su interior en salones, capillas, vestibulos y escaleras a base de relieves de escayolas coloreadas y pintura al temple en paredes y techo. Actualmente se conservan las del "salón pompeyano", que reproduce motivos del IV estilo pompeyano y que se desborda hacia el techo con motivos de grutescos y figuras alegóricas. Ello nos indica una decoración de tradición dieciochesca y gusto neoclásico, con vinculación al clasicismo romano, acorde con el clasicismo arquitectónico de su arquitectura.

Como el edificio, son de autor desconocido aunque su estilo y técnica hace pensar en un pintor decorador. Recordemos que en las posibles fechas de ejecución, entre 1820-30, no había en Málaga profesionales cualificados para este tipo de trabajo, ni para otros de carácter artísticos ya que los retratos del matrimonio Heredia fueron realizados por un pintor ingles.

La Concepción, edificada años más tarde, a partir de 1850, mantiene el mismo estilo que la anterior. La vivienda, pensada para conseguir una integración con el exte-

${ }_{27}$ GARCíA GÓMEZ. F.: "La casa palacio" en SAURET GUERRERO, T.: Patrimonio cultural de Málaga y su provincia. Patrimonio Natural. Patrimonio Histórico artístico. Desde la Prehistoria hasta la Edad Media. Málaga, CEDMA, 1999, págs. 94-97. 


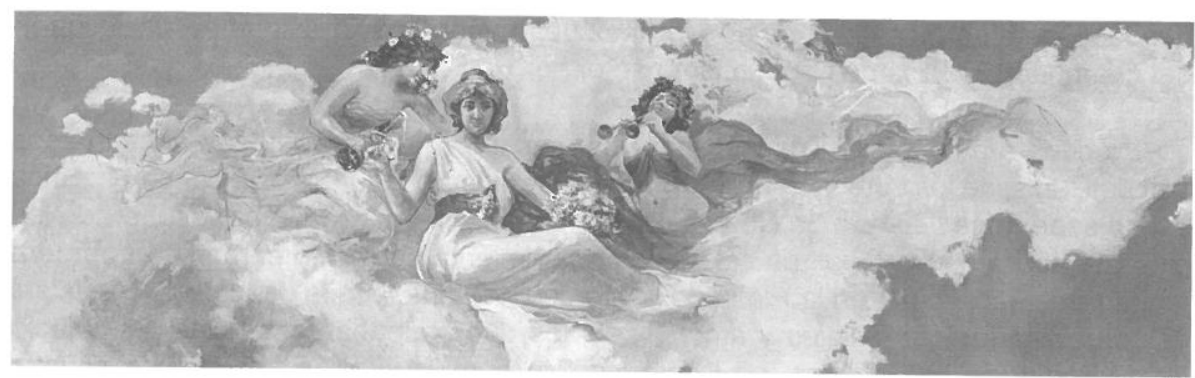

7. Alegoría del champang

rior, posee múltiples espacios para posibilitar esa convivencia con la naturaleza, y los documentos gráficos que se conservan de su interior reflejan unos ambientes íntimos y acogedores, marcados por el tono de la sobriedad burguesa, aunque no exentos de calidad y categoría y en los que no se aprecia ese despliegue festivo de la decoración mural $^{28}$, sin embargo, en el interior del templete clásico que acogía las principales piezas de la colección loringiana, se decoró con motivos pompeyanos como complemento a la función y forma de la edificación.

La mayoría de las decoraciones que conservamos son del último tercio del siglo XIX, y pertenecen, o pertenecían, a locales públicos y a domicilios privados de la sociedad alta y media malagueña. Se caracterizan por la libertad de técnica y soporte, a veces óleo o temple, sobre lienzo o estuco, y un tratamiento iconográfico que oscila desde el mantenimiento de los elementos decorativos tradicionales (figuras alegóricas, celajes), recabados del barroco, a opciones renovadoras que proceden de la pintura de caballete, como nos lo ofrece los lienzos adosados al techo de la antigua Joyería Ghiara en calle Granada, que no son más que cuadros ubicados en el techo, o algunas escenografías de Denis en donde traslada motivos específicos de su especialidad fortunysta.

Entre estos ejemplos comentados, a parte de los ya citados del Liceo Artístico y Literario de 1870 y del Teatro Cervantes, de la misma fecha, se ha documentado decoraciones en establecimientos comerciales como las de la actual Farmacia Mata, en calle Larios, de principios de siglo, una Alegoría de la Farmacia realizada por Moreno Carbonero; en Calle Granada, la citada antigua joyería Ghiara, en el siglo XX ocupada por la Confitería La Española, tenía su techo decorado con lienzos de Denis, Nogales, Blanco Coris, Cappa. Decoraciones presentaban la antigua Librería Denis en la Calle Santa Lucía y el Café Universal, en donde después se situó Almacenes el Águila y hoy lo ocupa una entidad bancaria; el Café de la Loba encargó en 1878 a Antonio Matarredona una alegoría para el Casino de Recreo ${ }^{29}$; el Círculo Mercantil tenía una Alegoria

\footnotetext{
${ }^{28}$ GARCÍA GÓMEZ. F.: La Concepción, testigo del tiempo. Málaga, Jardín Botánico-Histórico La Concepción, 2003.

${ }^{29}$ Avisador Malagueño, viernes 22 de febrero, 1878.
} 
del descubrimiento de América de Martínez de la Vega y el Círculo Militar la Alegoría del champagne realizada por el mismo autor.

En cuanto a los domicilios privados, los más importantes conjuntos conservados son de Denis, de los que hablaremos más adelante, pero algún otro se conserva. En la actual sede de la Jefatura de Costas, Paseo de la Farola $n^{0} 12$, se ha recuperado las pinturas del salón principal, un celaje con rompimiento de nubes enmarcado por una moldura de escayola ${ }^{30}$; en la Plaza de la Merced $n^{\circ} 2$, los techos de la planta principal están decorados con celajes y amorcillos ${ }^{31}$; los que ocupaban estancias del palacio del Marqués de Valdecañas, en la calle de su nombre, fueron trasladados a unas dependencias nuevas del Liceo, convertido ya en Conservatorio María Cristina, que representas putteis flotando sobre fondo de cielo $^{32}$ y en el salón de actos de la sede de la Plaza de la Marina de la Entidad UNICAJA se trasladaron otras decoraciones, con escenas alegóricas. Probablemente existirán algunas más, pues paulatinamente se están recuperando piezas ocultas y desconocidas.

La característica de estas pinturas es la de su escasa calidad, nulo interés iconográfico y fin meramente decorativo.

Realmente, el "tono" de los interiores burgueses lo daba la decoración mobiliar, que se caracterizaban por su abigarramiento, en donde el cúmulo de objetos convertían a estos espacios en pequeños museos en donde imperaba el horror vacui. Como dirá Guerrand: Cuanto más se avanza a lo largo del siglo, más se va pareciendo el apartamento burgués, en su mobiliario, a un almacén de antigüedades en el que la acumulación parece ser el único principio director de la composición interior del espacio ${ }^{33}$.

A pesar de ello, la nota de apoyo a la distinción de calidad de esos espacios la daba la pintura sobre muro, a veces en paredes y especialmente en techos, de ahí que se convirtiera en una práctica relativamente generalizada.

Esta demanda se ve confirmada por la especialización de artistas en esta modalidad. Desde 1862 se registra en Málaga nombres como el de Manuel Montesinos, valenciano de nacimiento que colabora en la decoración de los arcos de triunfo que se montan cuando la visita de Isabel II a Málaga en 1862. Las posibilidades de trabajo le aconsejan instalarse en la ciudad y montar un taller/escuela en la Plaza de la Merced, en donde formó a un colectivo de decoradores y escenógrafos que estuvieron activos en Málaga hasta principios del siglo $\mathrm{XX}^{34}$. Uno de ellos fue Antonio Matarredona, natural de Alcoy, que participa en 1870 en el traslado al techo de la decoración realizada por Ferrándiz para el Teatro Cervantes. Fue un asiduo decorador de las casas burguesas y un discreto pintor de caballete; terminó su carrera dedicado a la docencia en la

\footnotetext{
${ }^{30}$ GARCÍA GÓMEZ. F.: La vivienda.... Op. cit. pág. 682.

${ }^{31}$ Restaurados por la empresa Quibla Restaura he podido estudiarlos directamente durante su proceso de restauración.

32 SAURET GUERRERO, T.: José Denis... Op. cit., págs. 217-218.

33 GUERRAND, R-H.: "Espacios privados" en ARIÉ, P., DUBY, G. (Dirs.): Historia de la vida privada. Madrid, Taurus, 1991, pág. 37.

${ }_{34}$ JORGE ARAGONESES, M.: Pintura... Op. cit., págs. 85-86. SAURET T.: El siglo... Op. cit., págs. 706707.
} 


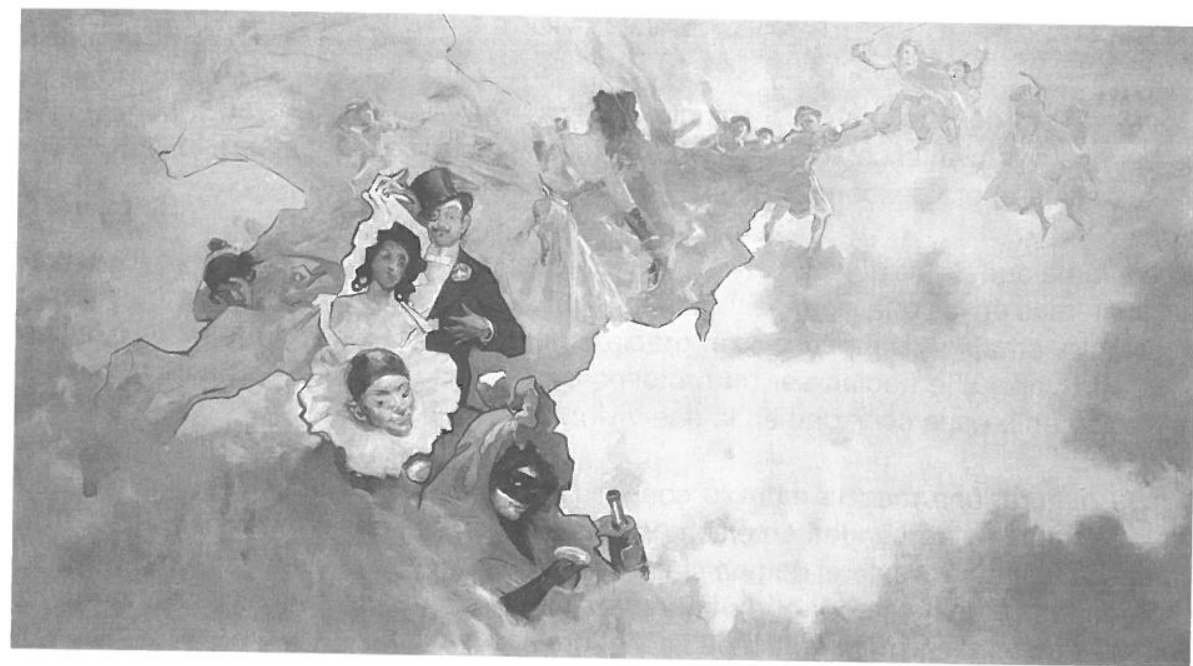

8. Escena de carnaval

Escuela de Bellas Artes impartiendo la signatura de Perspectiva. Otro oscuro pintor, Manuel Carreto Mariño, de procedencia gaditana, también colaboró en la decoración del Teatro Cervantes. Discretísimo pintor se dedicó a la decoración de interiores sugiriéndonos, esas "decoraciones estilo árabe" que sus trabajos serían más de escayolista que de pinturas decorativas con alguna calidad artistica. Por último, tenemos registrado el nombre de Blasco y Pérez entre los colaboradores de Ferrándiz en el Teatro Cervantes, pero nada más de él se sabe.

Lo habitual fue que los propietarios recurrieran al elenco de pintores activos en la ciudad. Ya desde mediados de siglo se eligieron profesores de la Escuela para estos encargos, registrándose la firma de Ángel Romero como uno de los primeros pintores escenógrafos de la ciudad, aunque de él solo conozcamos que colaboró en los arcos de triunfo levantados en Málaga para la venida de Isabel II. Pero el hecho de una demanda y práctica continuada por parte de las firmas de prestigio, esta confirmado por el interés de nuestros pintores, como por ejemplo Ferrándiz. Moreno Carbonero, Lengo, Maqueda y Martínez de la Vega, por participar en el certamen-concurso que convoca la Universidad de Barcelona para decorar el paraninfo en $1880^{35}$. Sin duda, entre ellos y como uno de los que dejó mejores trabajos, hay que incluir a José Denis Belgrano.

${ }^{35}$ A.A. Bellas Artes de San Telmo, 1876-1882. comunicación 14 de enero, 1880, fols. 95-96. 


\section{DENIS BELGRANO, DECORADOR DE INTERIORES}

Viene a propósito centrar el estudio del tema en la figura de José Denis Belgrano por la incorporación al catálogo de esta modalidad pictórica un nuevo ciclo de decoraciones hasta ahora desconocido.

La fama que Denis alcanzó en su época, y después, no es casual. Su modo de pintar, los temas en los que se especializó, su propia personalidad, abierta aunque tímido y discreto, amable y simpático, con gracia y buen talante, como lo describe Antonio Canovas Vallejo, le hacian ser un prototipo de Málaga y de lo malagueño y encajar perfectamente en la sociedad en la que vivió y dejó su herencia.

Su pintura, una mezcla entre lo convencional y lo moderno, pero especialmente festiva, amable y tremendamente comercial, representa el gusto más generalizado de su época, especialmente el de una clase social que emerge durante todo el siglo y se sitúa en las cotas del poder por primera vez en la historia, no solo en el campo de la política sino especialmente en el de la economía.

Una clase social culta, pero con moderación, más preocupada por acumular riquezas y estableces un status de representación que en ser intelectuales; que demandaba un producto artístico que tuviera apariencia de lo nuevo, que "sonara" a actual, pero sin caer en los despropósitos de lo revolucionario, que generaba provocación, desprecio por las normas y, en muchos casos, cambios.

De Francia a Málaga, este estamento fue aprendiendo los modos modernos del Romanticismo primero, y del Realismo después, y los fue acoplando a sus intereses. Por eso en Francia surgió el "realismo burgués", que no era más que cierta apariencia de lo moderno dentro del lenguaje ecléctico imperante en la Monarquia Luis Felipe, porque esa supuesta lectura actual de las formas se combinaba demasiadas veces con temas inspirados en épocas pretéritas y a su traducción se le exigía, siempre, una habilidad técnica que se ponía en discusión con los principios de instantaneidad, objetividad y contemporaneidad de la pintura moderna. De todo ello surgieron las firmas de Bretón, Meissonier , Fortuny.. y de éste a Málaga pasando por Ferrándiz llegamos a Denis.

Denis supo asimilar de su maestro Ferrándiz todo ese discurso del realismo mezclado con Fortuny en el que la vida debía ser contada, pero no siempre desde la contemporaneidad y la objetividad. Denis supo ser realista cuando trataba a sus personajes populares y recreaba sus situaciones cotidianas pero también supo que las miserias del pueblo no eran asuntos que casaran bien con los lujosos interiores domésticos de sus clientes, por ello se cuidó mucho de provocar con sus desarrapados y sus vidas y los edulcoró a fuerza de idilios amorosos, fiestas flamencas, toros y música, y les hizo parecer felices al retratarlos cuando paseaban, coqueteaban, bailaban, guisaban, cosian, bebian o incluso sufrían.

Pero no todo fue pueblo; como un supuesto realista, le interesaba el día a día de sus conciudadanos, aquellos con los que compartia lecturas, charlas, amistad o relaciones sociales. Al registrar sus situaciones cotidianas se mantuvo más complaciente y las hizo pasear por teatros, salones de bailes, jardines, acontecimientos religiosos, festivos o 
9. Pedro de Ribera. Siempre lo mismo

en veladas domésticas. Siempre desde la mirada distante del pintor realista, moderno, pero nunca provocando actitudes reflexivas ni críticas, ni denuncias; como un perfecto ecléctico.

Junto a estos intereses temáticos no abandonó uno de los géneros de mayor aceptación en la época, el de asuntos veraces trasladados a épocas pretéritas. Él escogió el siglo XVIII, como Meissonier y Fortuny, y se especializó en "pintura de casacón", por lo que también se adecuó a su técnica: minuciosa, de pincelada ajustadísima, de color brillante, y explosión de luminosidad.

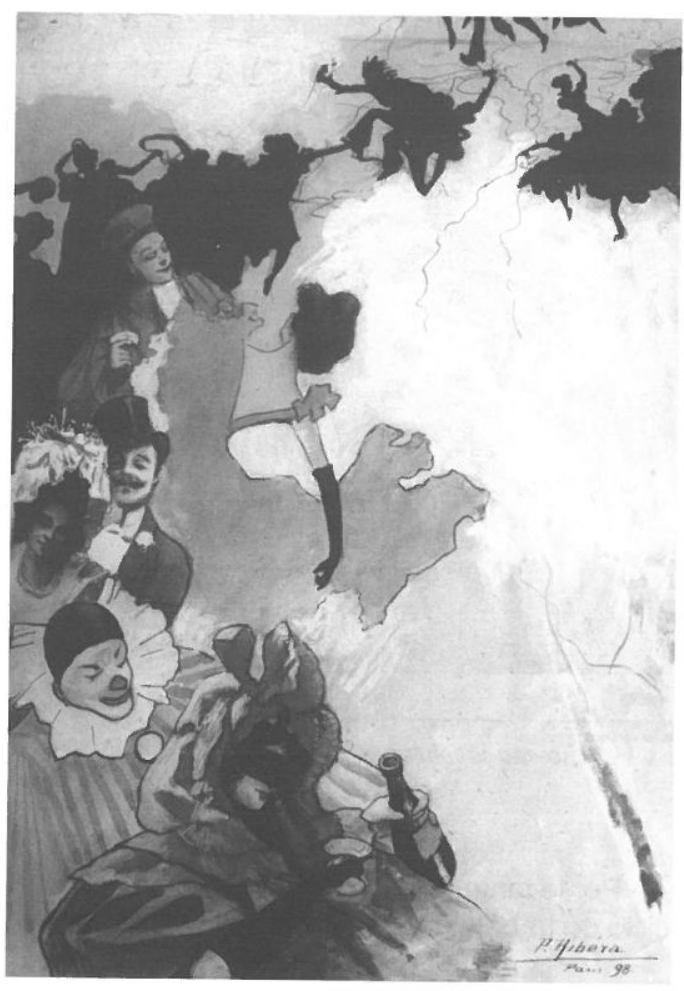

No fue un fortunysta más. Supo interpretar al de Reus en su justa medida; al de La vicaría y al de las playas de Porticci, que es igual que decir que al pintor de raiz romántica que recicló a un Goya populista y nacionalista, de majos y manolas, mantillas y morillas y taurino y al que hizo de la luz el factor identificador de las atmósferas del sur y el protagonista de unos ambientes donde el color se presenta siempre brillante y luminoso, como el que pinta las atmósferas malagueñas.

Trabajó todos los géneros pictóricos menos el de Historia, y las circunstancias de la vida le hizo ser decorador de interiores.

El primer trabajo consignado de esta modalidad fue el realizado para la sociedad cultural El Liceo de Málaga. En su archivo particular Denis conservaba fotografias de los bocetos de La Aurora y de El tocado de Venus, firmados y fechados en 1870 , lo que hace suponer que el encargo se realizó en ese año, aunque el momento de crisis que la sociedad atravesaba en ese año hace difícil pensar que la institución se embarcara en un proyecto de remodelación de su interior. Precisamente, en esa fecha, se recoge un artículo en la revista El Álbum, del 7 de febrero de 1870, en el que se comenta:

El "Liceo" no da señales de vida, entregado a sus pasatiempos de billar y tresillo.

Va pasando todo el invierno y el mutismo del "Liceo" hace presentir que cuando más, el templo de la enseñanza y del instructivo recreo, se convirtió en breve en campo de Tepsicore con sus atronadoras y estériles mascaradas. 


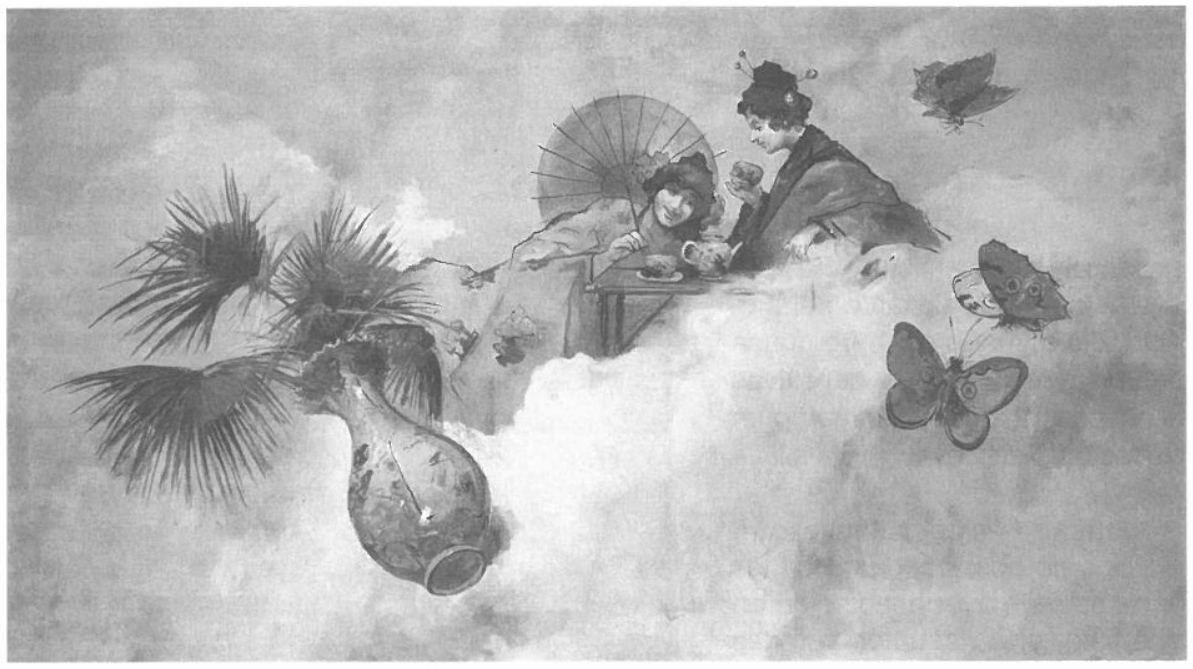

10. Escena japonesa

Por lo tanto, parece lógico pensar que los bocetos fueran realizados como un ejercicio de trabajo o para un encargo diferente que no se llevó a efecto.

Posteriormente, cuando en 1872 la sociedad se reorganiza, sería cuando la junta directiva se dirigiría a él y a Martínez de la Vega para hacer la decoración del techo del salón de actos, aceptando la propuesta de Denis sobre sus bocetos.

Los estudios están realizados a modo de cuadros de caballete, con una técnica muy precisa y académica, así como el tratamiento de la iconografía mitológica, basada en esquemas tardo barrocos y tradicionalistas.

Parece lógico pensar que su base iconográfica estuviera en modelos aprendidos durante su estancia en Roma entre 1862 a 1864, cuando estuvo pensionado por el Marque de Guadiaro en la Ciudad Eterna, ya que se advierte inspiraciones en trabajos de Bronzino, concretamente de su venus de la National Galery de Londres, y en general de esquemas tardo manieristas de Zuccaro y otros artistas romanos.

La traducción a tamaño real hizo aligerar el trazo, perder nitidez las formas y expresión las figuras, resultando mucho más rígidas que en el boceto, aún así, contrastadas con la pintura de Martínez de la Vega, constituyen un relato de dinamismo y expresividad que vitaliza el resultado del conjunto

Estas pinturas debieron crearle al autor fama como pintor de decoraciones pues a partir de ellas, la documentación da cuenta de otros encargos. 
Uno de los más celebrados fue el que realizó para Tomás Heredia en 1876, a la vuelta de su segunda estancia en Roma, para su casa de la Alameda. Destruida en un incendio provocado, no conocemos el resultado.

El refrendo que le supuso la confianza de este comitente hizo que otros particulares le requirieran para las decoraciones de sus interiores, uno de ellos fue el de la familia de Francisco Martos Roca, prestigioso abogado a quien retrata cuando niño, para quien realizó la decoración de su casa en Hoyo de Esparteros, desaparecido igualmente, así como para la joyeria Guiara en Calle Granada en donde reprodujo una Napolitana, en paradero desconocido actualmente.

Sin saberse su ubicación original se conocen once lienzos que ocuparon los techos de entidades y domicilios malagueños. Uno de ellos, que representa La Modelo, en colección particular, y los diez restantes pertenecientes a la colección de Unicaja.

De distintas iconografías y tamaños parece que dos de ellos, La Modelo y Amorcillos estuvieron colocados en un mismo domicilio ${ }^{36}$; del resto, una Alegoría del Amor (El tocado de Venus), por su tamaño y forma sugiere un encargo público o una vivienda de amplias estancias, mientras que los siete restante fueron realizados para una ampliación que se fue a efectuar en el Liceo alrededor de 1898 y cuyo destino sería unas dependencias para casino, obra que realizaría Gerónimo Cuervo. Los lienzos nunca ocuparon su lugar pues sirvieron de pago para el contratista que los colocó en su domicilio ${ }^{37}$.

Las fechas del conjunto de piezas decorativas que se conocen hasta este momento de Denis es amplia, pues si bien la Alegoría del Amor parece, por la técnica de ejecución, muy cercana a los trabajos del Liceo de 1872, el resto, de factura mucho más suelta y despreocupada, sugiere unos años más tardios, alrededor de 1898-1900.

Iconográficamente el mas interesante es La modelo (FIG. 2), ya que estamos ante una versión libre de las tradicionales iconografías para las musas. Por el gesto del mentón descansando sobre la mano y la larga túnica representaría a Polimnia, musa de la pantomima, por lo que haría referencia a las artes escénicas, sin embargo aparece rodeada de objetos alusivos a la pintura, aunque su gesto no guarde relación con el concebido para su alegoría. Por otra parte, la posición de la mano sobre la mejilla es asociable a la representación de la musa de la poesía épica, Calíope, ya que se la representa sedente y meditabunda con el stilo y las talillas en las manos, sustituidos aquí por el cuaderno de dibujo y la paleta los pinceles del segundo plano. La ambientación de la estancia en donde se sitúa a la figura femenina nos vuelve a hacer referencia a las artes plásticas y al clasicismo en el busto de escayola tirado en el suelo, alusión a la academia y a sus enseñanzas, por lo que en su conjunto el personaje femenino se

\footnotetext{
${ }^{36}$ En el anverso de ambos lienzos hay adheridos material del techo y restos del enmarque que tuvieron, al ser de los mismos materiales se le supone una misma base, por lo tanto un mismo lugar de procedencia. La información me ha sido transmitida por los restauradores del equipo QUIBLA RESTAURA, a quien le agradezco los datos, especialmente a Francis por sus constantes atenciones.

${ }^{37}$ Los datos me fueron transmitidos por sus anteriores propietarios en 1977. Sobre ellos vid. SAURET GUERRERO, T.: José Denis... Op. cit., pág. 218.
} 


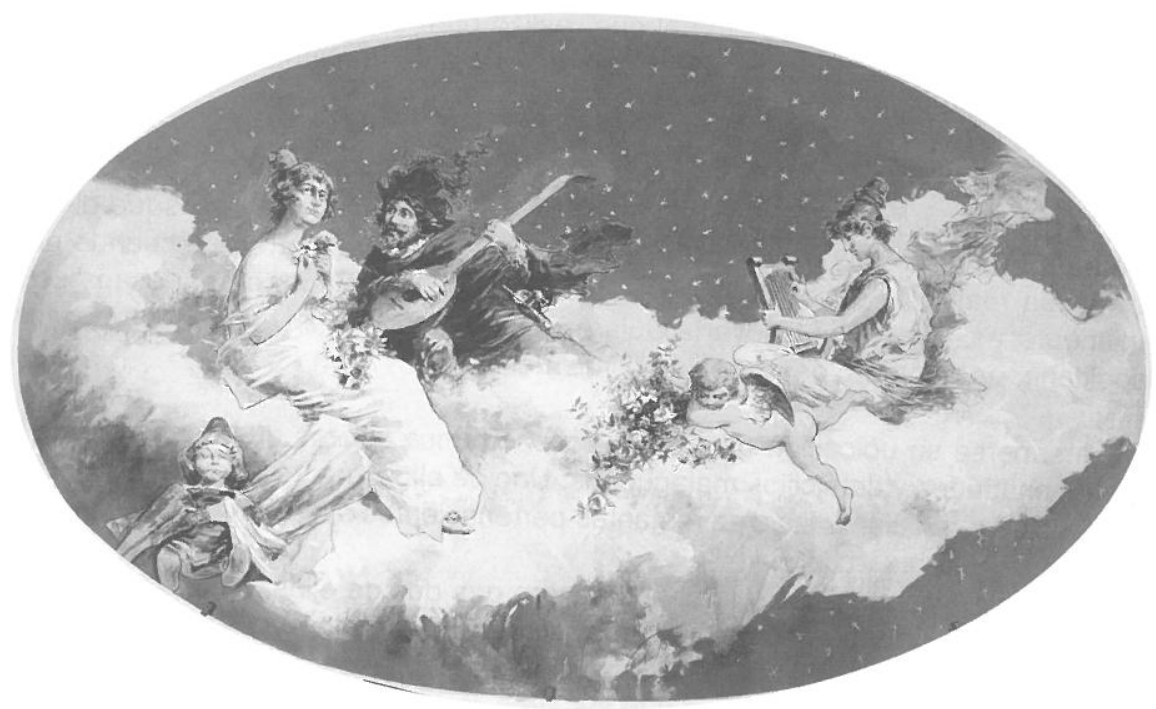

11. Personajes de comedia

asemeja a una modelo descansando de una sesión de posado con lo que la erudición del tema se frivoliza hasta llevarnos a una representación amable, ornamental y de un resultado técnico suelto, espontáneo y expresivo, que convierte el solemne tema académico en un divertido juego pictórico, muy apto para decorar un interior en donde las función de su uso debía ser de carácter lúdico.

De fechas muy cercanas debe ser la representación de Venus para una vivienda particular, actualmente en la colección de Unicaja, que técnicamente se ajusta a la empleada en los lienzos citados anteriormente pero que no parece guardar relación con ellos por su tamaño, ni con Personajes de Comedia, de similar tratamiento técnico pero con un tema que se distancia de los más convencionales anteriormente comentados, por lo que deducimos que perteneció a otro conjunto decorativo.

Sin embargo, el conjunto de siete lienzos realizados para la ampliación del Liceo si tienen cierta coherencia iconográfica, al ser temas alusivos a lo lúdico y a lo mitológico, concebidos para decorar diferentes estancias. Solo hay una licencia; la del Idilio (FIG. 1), pareja de personajes dieciochesco que daban el sello de identidad al trabajo
de Denis.

En cuanto a sus fuentes iconográficas son variadas. Si algunas, en las que el tema mitológico tradicional es el elegido, parece que responden a unos esquemas establecidos para estos asuntos, como puedan ser los empleados para los Putteis (FIGS. 3-4-5), Musa (FIG. 6) o El tocado de Venus (FIG. 12), otras las busca en el imaginario contemporáneo que recaba de las revistas ilustradas del momento. Así parece que 


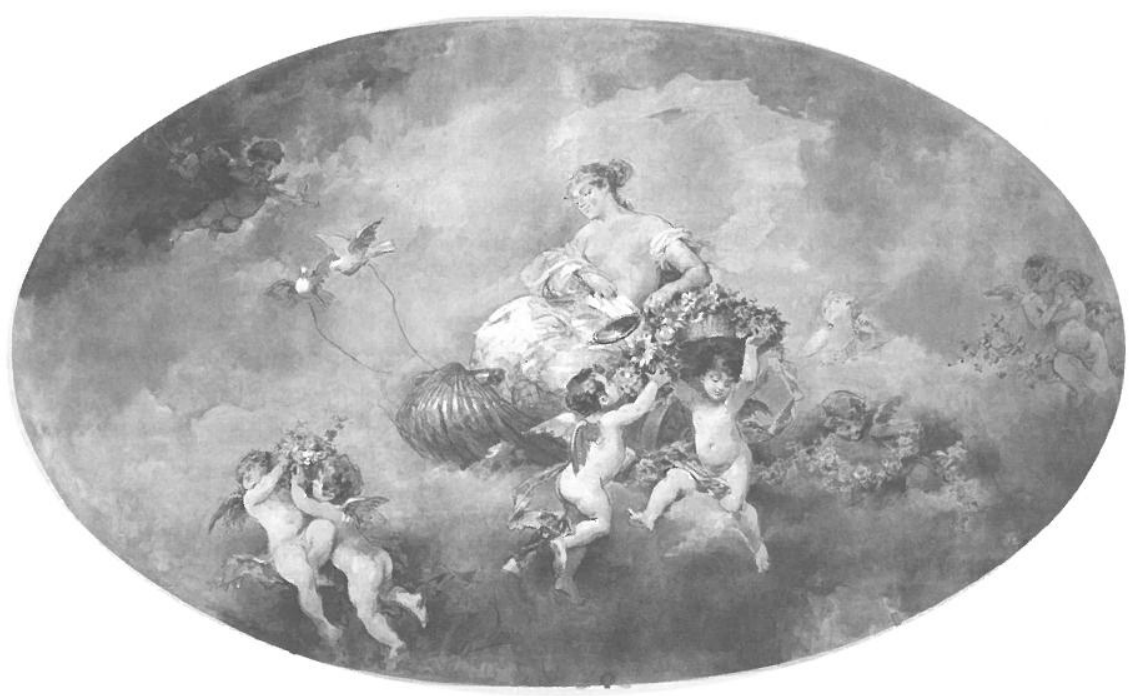

12. El tocado de Venus

trabaja en Personajes de comedia (FIG. 11), Alegoria del Champang (FIG. 7), o Escena de carnaval (FIG. 8). concretamente, esta última esta calcada de una ilustración publicada en la Revista Blanco y Negro de $1898^{38}$ (FIG. 9), firmada por Pedro Ribera y titulada Siempre lo mismo.

Denis cambia el formato vertical de la revista por el horizontal más adaptable al óvalo del techo al que irá aplicado, y expande la escena hacia la derecha ganando ésta en movilidad y riqueza expresiva. Le añade algunos toques personales, que sin duda hacen aumentar la calidad de la escena, mediante un tratamiento de las figuras a las que ha trabajado desde la estética de la inmediatez, provocando una comunicación directa del espectador con los personajes, que miran y dialogan con los festejantes, mientras que Ribera en la ilustración impresa se muestra impersonal y distante, realizando un trabajo de menos compromiso y calidad, por lo que se deduce que Denis se "inspiraba" en material gráfico peroque trabajaba sobre él para conseguir resultados más personales.

Precisamente en esta pieza, sabe reconvertir esa ligereza de pasta y trazo que hace habitual en sus últimos años, en una técnica dirigida a manchar el lienzo desde esa intención de la modernidad de concretar zonas cromáticas autónomas dentro

${ }_{38} \mathrm{~N}^{\circ} 355,9$ de febrero de 1898. Aparecer publicada en PÉREZ ROJAS, J.: La ciudad placentera. De la verbena al cabaret, Catálogo de la exposición.... Valencia, Museo del Siglo XIX, 9 de junio al 30 de septiembre de 2003, pág. 199. 
de la composición. Objetivos que se resuelven plenamente en el relato figurativo del centro de la escena y en la superficie anicónica de la derecha, que con aspiración de recordar un celaje, se convierten en un espacio lleno de expresividad por la limpia
disposición de los tonos.

Por otra parte, en esa contraste que establece entre manchas que sugieren y formas que describen, nos lanza un guiño hacia su apuesta por trabajar acercándose a la modernidad finisecular, algo inusual en su catálogo.

Este gesto nos informa sobre una realidad, la de que aunque la mayoría de los pintores españoles, especialmente los que se movian exclusivamente en círculos provinciales, no apostaron por la modernidad ni tuvieron la intención de incluir al pais en la dinámica de la vanguardia, contactaron con ella a través de fuentes gráficas, especialmente, y entendieron el camino por el que iba el arte moderno pero, o bien no pudieron engancharse a él, o no quisieron por sentirse más seguro en el territorio de la comercialidad. El caso de Denis no es único. 